\title{
Uterine Prolapse during First Trimester Managed with Vaginal Pessary
}

\author{
Ilk Trimesterdeki Uterin Prolapsusun Vajinal Pesser \\ ile Tedavisi
}

\section{Abstract}

Uterine prolapse during pregnancy is a rare condition with an estimated incidence of 1:10,000-15,000 pregnancies. Premature labor and delivery are the most prevalent complications in pregnancies with pelvic organ prolapse. Various treatment methods from conservative approaches to surgery are possible. In this paper we report a 27 year-old patient who was treated with Arabin pessary due to uterine prolapse in the first trimester.

Keywords: pregnancy; uterine prolapse; vaginal pessary

\section{Öz}

Gebelikte uterin prolapsus nadir görülen bir durumdur, tahminen 10-15 bin gebelikte 1 görülür. Pelvik organ prolapsusu gelişen gebeliklerde en yaygın komplikasyon erken doğumdur. Konservatif yaklaşımdan cerrahiye kadar, çeşitli tedaviler mümkündür. Bu çalışmada, ilk trimesterde uterin prolapsus nedeniyle Arabin pesser ile tedavi edilen 27 yaşındaki bir hasta sunulmuştur.

Anahtar Sözcükler: gebelik; uterin prolapsus; vajinal pesser
Ozan Dogan', Alper Basbug², Aski Ellibes Kaya', Derya Basbug ${ }^{3}$, Cigdem Pulatoglu ${ }^{4}$

1 Department of Obstetrics and Gynecology, Sisli Hamidiye Etfal Training and Research Hospital, Istanbul, Turkey

2 Department of Obstetrics and Gynecology, Duzce University Hospital, Duzce, Turkey

${ }^{3}$ Department of Obstetrics and Gynecology, Private Clinic, Duzce, Turkey

4 Department of Gynecology and Obstetrics, Bayburt Government Hospital, Bayburt, Turkey

Geliş Tarihi /Received : 26.09.2017 Kabul Tarihi /Accepted: 25.01.2018

DOI: 10.21673/anadoluklin.339989

Sorumlu Yazar/Corresponding Author Ozan Dogan

Sisli Hamidiye Etfal Training and Research Hospital, Department of Obstetrics and Gynecology, Istanbul, Turkey E-mail: ozandogan02@hotmail.com 


\section{INTRODUCTION}

Uterine prolapse during pregnancy is a rare condition with an estimated incidence of 1:10,000-15,000 pregnancies (1). The related complications are discomfort, cervical desiccation and ulceration, urinary tract infection, acute urinary retention, abortion, preterm labor, fetal and maternal sepsis, and maternal death (2). Depending on the condition's severity and patient's preference, various treatment methods from conservative approaches to surgery are possible. Vaginal pessaries of different shapes and sizes are also a management option. In this report we present a patient with uterine prolapse in the first trimester who was successfully treated conservatively with Arabin pessary.

\section{Case}

A 27 year-old (G2 P1) woman with a complaint of inability to urinate for the past 3 days was referred to our emergency unit. The patient had discomfort and pain at the perineal area. She had no history of medication and was at the $13^{\text {th }}$ week of pregnancy. She had no history of urinary incontinence or uterine prolapse before her pregnancy, and suffered no other abnormalities during pregnancy either. Since the patient had pain, we suspected of other conditions of pregnancy such as abortus imminens. The obstetric USG revealed a live in utero singleton pregnancy with a normal amniotic fluid index, CRL: 13w1d (Figure 1). Additionally, the bladder was full of urine (globe vésical) (Figure 2). On pelvic examination there was evidence of grade 3 uterine prolapse and the cervical os was closed (Figure 3). The urinalysis test was negative, and there was no bacterial growth in the urine culture. Based on these results we decided on a conservative treatment. After the catheterization of the bladder, a 65-mm-diameter, 25-mm-high Arabin pessary was placed into the vagina to reduce the prolapse (Figure 4). After applying the pessary, the patient had no more complaints about urinary retention or uterine prolapse. The patient was able to urinate and discharged after the improvement of the symptoms. She was controlled weekly. The pessary was removed, disinfected and then replaced at each visit. She was followed up until the $36^{\text {th }}$ week. The results were satisfying. There were no signs of preterm labor, cervicovaginal infection or urinary retention. The patient gave birth at the 36th week by spontaneous vaginal delivery to a healthy baby.

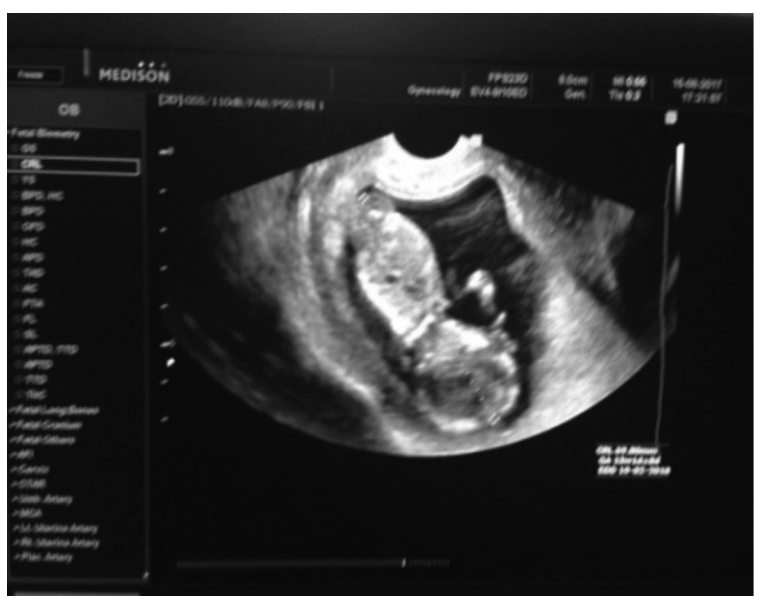

Figure 1. Normal singleton pregnancy

\section{DISCUSSION}

Uterine prolapse and acute urinary retention are rare conditions in pregnancy. Uterine prolapse occurs when pelvic floor muscles and ligaments stretch, weaken and no longer provide enough support for the uterus. The main causes of uterine prolapse may be difficult labor and delivery, trauma during labor, delivery of a large baby, cervical elongation caused by physiologic changes of pregnancy, increased intraabdominal pressure (chronic constipation etc.), congenital connective tissue disorders, obesity, and relaxation of the supportive ligaments $(3,4)$. Premature labor and delivery are the most prevalent complications in pelvic organ prolapse (5). In our patient uterine prolapse occurred in the first trimester of her second pregnancy. Since there were no other attributable risk factors in this case, we considered that this prolapse could be due to the physiologic changes in pregnancy.

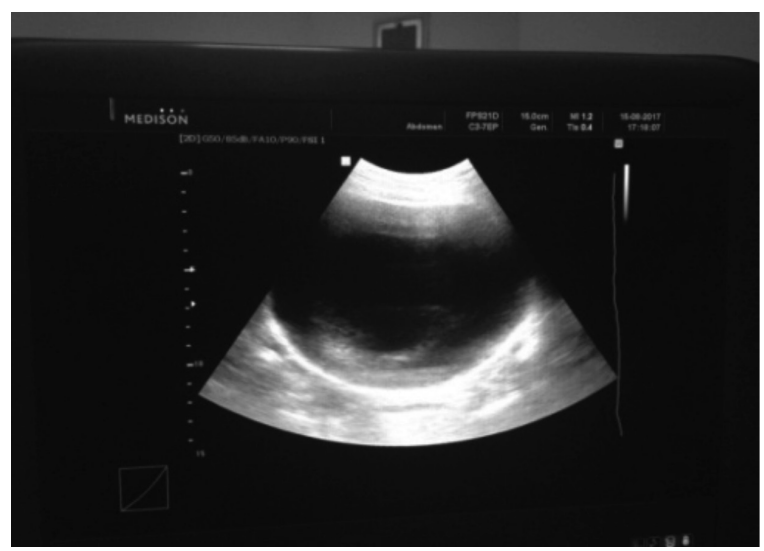

Figure 2. Globe vésical 


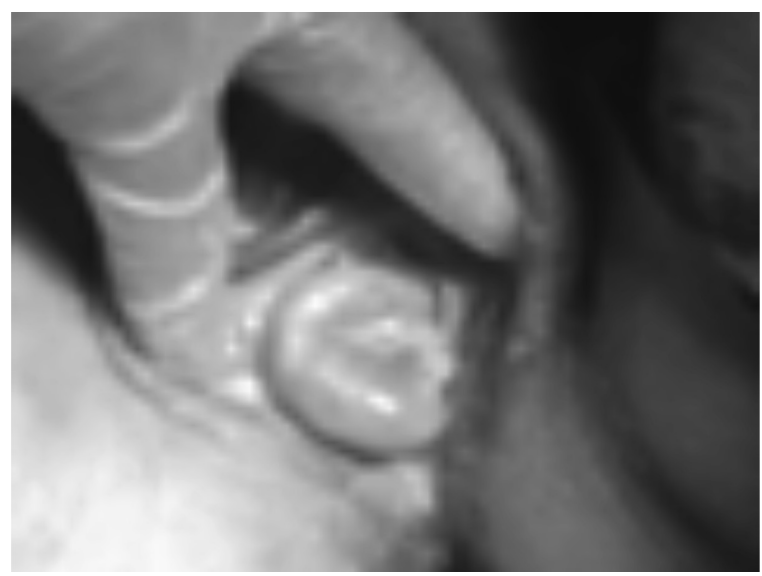

Figure 3. Uterocervical prolapse

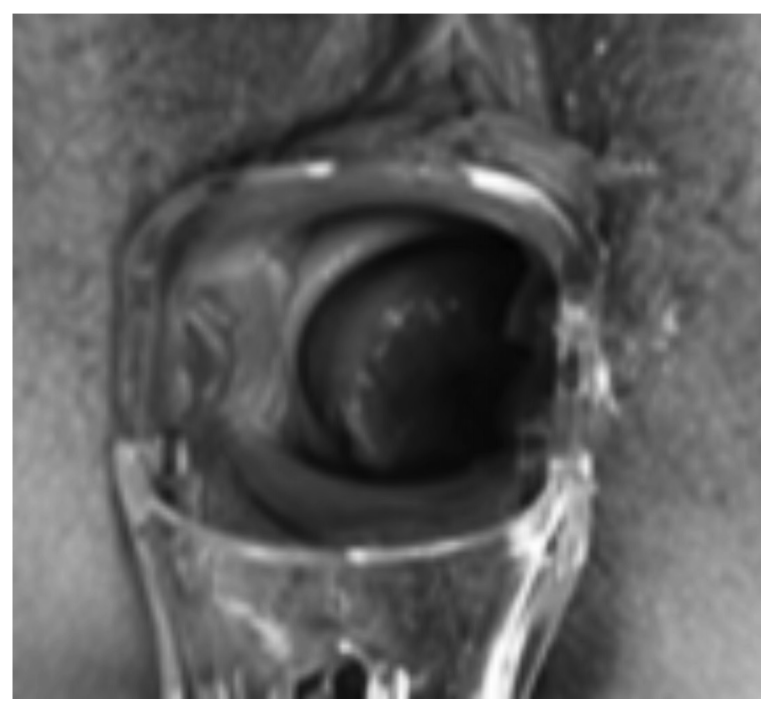

Figure 4. Treatment of uterocervical prolapse with vaginal pessary

The first attempts for treatment should be the drainage of the bladder and the reduction of the prolapse. A pessary could be an option to keep the uterus in a proper position and maintain a normal vesicoureteral angle (6). Pessaries can be placed easily. The silicone-coated ring pessary is more convenient, since it can be removed easily by the patient (7). Common complications with pessaries are vaginal discharge, mucosal erosions of the vagina and odor (8). Our patient did not develop any of these complications. In uterine prolapse during pregnancy, treatment depends on the condition's severity and the patient's preference. Management should be aimed at reducing complications, which can be overcome by use of vaginal pessaries. Successful management was achieved in our patient with an Arabin pessary.

\section{REFERENCES}

1. Guariglia L, Carducci B, Botta A, Ferrazzani S, Caruso A. Uterine prolapse in pregnancy. Gynecol Obstet Invest. 2005; 60:192-194.

2. Varras M. Uterocervical prolapse during pregnancy. Am J Case Rep. 2010;11:83-6.

3. Guariglia L, Carducci B, Botta A, Ferrazzani S, Caruso A. Uterine prolapse in pregnancy. Gynecol Obstet Invest. 2005;60:192-4.

4. Meydanli MM, Ustun Y, Yalcın OT. Pelvic organ prolapse complicating third trimester pregnancy. A case report. Gynecol Obstet Invest. 2005;61:133-4.

5. Keettel WC. Prolapse of the uterus during pregnancy. Am J Obstet Gynecol. 1941;42:121.

6. Chauleur C, Vulliez L, and Seffert P. Acute urine retention in early pregnancy resulting from fibroid incarceration: proposition for management. Fertil Steril. 2008;90(4):1198.e7-10.

7. Sulak PJ. Nonsurgical correction of defects, the use of vaginal support devices. Te Linde's Operative Gynecology, 8. ed., p. 1082-3.

8. Buyukbayrak EE, Yllmazer G, Ozyapi AG, Kars B, Karsidag AY, Turan C. Successful management of uterine prolapse during pregnancy with vaginal pessary: a case report. J Turk Ger Gynecol Assoc. 2010;11:105-6. 